\author{
Matgorzata Adamska-Chudzińska \\ Justyna Pawlak
}

\title{
Znaczenie poczucia wpływu na organizację w kształtowaniu zaangażowania pracowników*
}

\section{Streszczenie}

W sytuacji wzrastającej konkurencyjności i dynamicznie zmieniających się warunków funkcjonowania współczesnych organizacji coraz istotniejsze staje się pozyskanie i zatrzymanie pracowników, którzy nie tylko posiadają wysoki poziom kompetencji, ale gotowi będą również identyfikować się z celami i misją organizacji. Istotne znaczenie w tym zakresie ma doświadczanie przez pracowników poczucia wpływu na rzeczywistość organizacyjną. Celem artykułu jest zaprezentowanie i omówienie wyników badań, w których podjęto próbę sprawdzenia związku pomiędzy poczuciem wpływu na organizację a gotowością pracowników do angażowania się w pracę oraz ich przywiązaniem do organizacji. Rozróżniono dwa poziomy poczucia wpływu na organizację: pierwszy wiąże się z możliwością zgłaszania własnych innowacyjnych propozycji doskonalących procesy operacyjne, a drugi dotyczy określonego zakresu autonomii na stanowisku pracy. Uzyskane wyniki potwierdziły występowanie współzależności pomiędzy poczuciem wpływu na organizację a zaangażowaniem w aspekcie afektywnym i lojalnościowym.

Małgorzata Adamska-Chudzińska, Uniwersytet Ekonomiczny w Krakowie, Wydział Ekonomii i Stosunków Międzynarodowych, Katedra Psychologii i Dydaktyki, ul. Rakowicka 27, 31-510 Kraków, e-mail:achm@uek.krakow.pl

Justyna Pawlak, Uniwersytet Ekonomiczny w Krakowie, Wydział Ekonomii i Stosunków Międzynarodowych, Katedra Psychologii i Dydaktyki, ul. Rakowicka 27, 31-510 Kraków, e-mail: justyna.pawlak@uek.krakow.pl

* Artykuł powstał w wyniku realizacji projektu badawczego finansowanego ze środków przyznanych Wydziałowi Ekonomii i Stosunków Międzynarodowych Uniwersytetu Ekonomicznego w Krakowie w ramach dotacji na utrzymanie potencjału badawczego. 
Równocześnie stwierdzono, że doświadczanie poczucia wpływu na jednym lub na drugim poziomie w podobnym stopniu wpływa na zaangażowanie i przywiązanie organizacyjne.

Słowa kluczowe: pracownik, poczucie wpływu w pracy, zaangażowanie organizacyjne, organizacja.

Klasyfikacja JEL: M54, J24.

\section{Wprowadzenie}

Narastająca zmienność i niepewność warunków funkcjonowania współczesnych organizacji powoduje, że od pracowników oczekuje się znacznie więcej niż tylko wysokiego poziomu wiedzy i umiejętności. Ważnym aspektem aktywności zawodowej staje się takie zaabsorbowanie pracą, które skutkować może efektywnym rozwiązywaniem zadań o podwyższonym stopniu trudności oraz wykraczaniem poza podstawowe obowiązki i typowe rozwiązania. Tym samym problematyka zaangażowania organizacyjnego i jego uwarunkowań zyskuje wśród menedżerów coraz większe zainteresowanie. Dotyczy to m.in. odkrywania istotnego związku pomiędzy zaangażowaniem a zdolnością człowieka do kreatywnego i innowacyjnego działania w sytuacjach zmiennych i niepewnych.

W tworzeniu warunków sprzyjających wysokiemu poziomowi zaangażowania organizacyjnego warto wykorzystać czynniki istotnie z nim korelujące. Jednym z nich jest odczuwanie przez pracowników możliwości wpływania na rzeczywistość organizacyjną. Specyfika tego czynnika wyraża się w postawie kadry zarządzającej, która przejawia się w uznaniu pracowników za podmioty zdolne kreować rzeczywistość organizacyjną zgodnie z posiadanymi kompetencjami i doświadczeniem. Z kolei niedocenianie możliwości pracowników skutkuje znikomym wpływem lub brakiem wpływu na funkcjonowanie organizacji, a zarazem niewielkim zainteresowaniem menedżerów dzieleniem się władzą.

Celem niniejszego artykułu było zweryfikowanie na podstawie badań empirycznych, w jakim stopniu poczucie wpływu współwystępuje z angażowaniem się pracowników w działalność organizacji przy uwzględnieniu różnych typów zaangażowania oraz spodziewanych skutków dla pracownika i organizacji. Do zbadania poziomu zaangażowania wykorzystano skalę przywiązania do organizacji J. Meyera i N. Allen, natomiast poczucie wpływu zbadano za pomocą autorskiego kwestionariusza pn. „Poczucie wpływu pracowników na organizację”. W analizie rezultatów badawczych rozróżniono dwa zakresy poczucia wpływu w pracy. Pierwszy wiąże się z możliwością zgłaszania przez pracowników własnych innowacyjnych propozycji lub korekt doskonalących przebieg procesów operacyjnych i działań pozaoperacyjnych oraz ewentualnego ich wdrażania. Drugi poziom dotyczy pozostawiania pracownikom określonego zakresu autonomii na stanowisku pracy przy założeniu, 
że dysponują odpowiednimi kompetencjami i doświadczeniem zawodowym. Założono, że wyższy poziom poczucia wpływu silniej oddziałuje na zaangażowanie pracownika. Badania będące podstawą analizy zostały zrealizowane w Katedrze Psychologii i Dydaktyki Uniwersytetu Ekonomicznego w Krakowie.

\section{Poczucie wpływu na rzeczywistość organizacyjną jako jedna $\mathrm{z}$ determinant aktywności zawodowej}

Podejmując problematykę poczucia wpływu, należy zwrócić uwagę na fakt, że może się ono wiązać z uwarunkowaniami podmiotowymi lub środowiskowymi. W klasycznym ujęciu J.B. Rottera [1990] poczucie wpływu i umiejscowienia kontroli (locus of control) jest jedną z charakterystyk osobowości, względnie trwałą, ukształtowaną we wczesnym okresie rozwoju człowieka. Wiąże się ono ze sposobem postrzegania przez ludzi związku pomiędzy własnym działaniem a otoczeniem, które określić można w kategoriach wpływu bądź zależności. Zdaniem J.B. Rottera wyróżnić można dwie orientacje związane $\mathrm{z}$ wewnętrznym lub zewnętrznym umiejscowieniem kontroli. W pierwszym przypadku mamy do czynienia z osobą przeświadczoną o własnym wpływie na otoczenie i zdarzenia, a w drugim z osobą, która ma poczucie, że jest zależna od sił zewnętrznych: innych ludzi, losu itp. To subiektywne przekonanie o swoich możliwościach wpływu i oddziaływania na otoczenie w dużym stopniu wpływa na motywację do działania, a także na jego rezultaty. Badania potwierdzają, że istnieje związek pomiędzy wewnętrznym poczuciem kontroli a większą aktywnością i większym zaangażowaniem ludzi w sytuacje zadaniowe [Gliszczyńska 1990].

Niezależnie jednak od trwałej predyspozycji jednostki okoliczności zewnętrzne również wpływają na to, czy u jednostki ukształtuje się przekonanie o możliwości wpływania na otoczenie, czy też konieczności podporządkowania się wymaganiom lub biegowi wydarzeń. W środowisku pracy kluczową rolę odgrywa w tym względzie styl zarządzania i kultura organizacji. Szczególnie silnie oddziałują na młodych pracowników mierzących się dopiero ze swoją nową rolą życiową i kolejnym zadaniem rozwojowym [Havighurst 1972], którzy z informacji zwrotnych od współpracowników i przełożonych oraz ze sposobu, w jaki są traktowani, czerpią wiedzę na temat swoich kompetencji, a także budują na ich podstawie obraz siebie w roli pracownika. Jeżeli otoczenie społeczne, a w tym konkretnym przypadku - organizacja, będzie danej jednostce przekazywać (oczywiście adekwatnie do poziomu wykonania zadań) informacje, że to, co robi, jest dobrze wykonane i sensowne, będzie się to przyczyniać do kształtowania się poczucia kompetencji oraz możliwości wpływu na otaczającą rzeczywistość. Dzięki zaspokojeniu potrzeby uznania będzie wtedy wzrastać jej satysfakcja z pracy. To z kolei 
przekładać się będzie na większą gotowość do wkładania wysiłku w wykonywanie swoich zadań [Conley 2015, s. 77]. Niezależnie jednak od wieku i stażu pracy bezpośredni przełożeni przez styl zarządzania i komunikacji wpływać będą na przekonania pracownika o zakresie jego autonomii i możliwości kształtowania środowiska pracy, co pośrednio lub bezpośrednio będzie uaktywniać lub hamować jego gotowość do zaangażowania organizacyjnego.

Należy podkreślić, że pojęcie zaangażowania jest nieostre i wielowymiarowe [Łaguna i in. 2015]. W pewnym uproszczeniu można przyjąć, że zaangażowanie to „względnie trwały stan pracownika prowadzący do podejmowania korzystnych działań na rzecz pracodawcy" [Moczydłowska 2013, s. 165], który w dużym stopniu determinuje efektywność pracy. Kształtuje go wiele czynników, które w różny sposób oddziałują na funkcjonowanie pracownika w organizacji. A. Bańka, R. Bazińska i A. Wołoska [2002, s. 66-67], analizując model zaangażowania organizacyjnego N. Allen i J. Meyera [1990], zauważają, że zatrudnieni, którzy charakteryzują się rozwiniętym zaangażowaniem afektywnym, są pracownikami bardziej wartościowymi dla organizacji niż pracownicy o słabszym zaangażowaniu afektywnym. Zależność tę potwierdzają także L.M. Shore i S.J. Wayne [1993].

Badania Developement Dimentions International (DDI) wskazują, że najbardziej zaangażowani pracownicy osiągają $85 \%$ celów, podczas gdy niezaangażowani 73\% [Bernthal 2009]. Z analiz Instytutu Gallupa oraz DDI wynika także, że dużemu zaangażowaniu towarzyszy zazwyczaj duża satysfakcja pracowników, która przekłada się na zwiększenie identyfikacji z organizacją.

Nie można zatem przecenić roli zaangażowania organizacyjnego, któremu poświęcono wiele badań i opracowań [Harter, Schmidt i Hayes 2002, Kostera 2008, Johnson, Groff i Taing 2009, Engaged Employees... 2012, Adamska-Chudzińska 2015]. Do teorii i praktyki zarządzania wprowadzono także podkreślające jego znaczenie pojęcie zarządzania przez zaangażowanie [Juchnowicz 2010]. Jest ono szczególnie ważne w czasach gospodarki opartej na wiedzy i dynamicznych zmian w otoczeniu organizacji, gdyż pozwala wykraczać poza obowiązkowe minimum, stwarzając przestrzeń do pojawienia się własnych pomysłów: innowacji, usprawnień i kreatywnych rozwiązań.

Na podstawie badań prowadzonych dla Institute for Employment Studies zdefiniowano katalog cech zaangażowanego pracownika. Znalazły się w nim: pozytywny stosunek do pracy i do organizacji, identyfikacja z organizacją, traktowanie innych z szacunkiem, bycie godnym zaufania, wykonywanie większej liczby zadań, niż wymaga tego pełniona funkcja, doskonalenie swoich umiejętności oraz szukanie możliwości poprawy wyników swojej pracy [Robinson, Perryman i Hayday 2004]. 
Aby jednak wyzwolić gotowość pracowników do angażowania się w działalność organizacji, konieczne jest stworzenie ku temu odpowiednich warunków. P.R. Bernthal [2009], omawiając problem zaangażowania pracowników, stwierdza, że pracownicy czują się zaangażowani, gdy znajdują osobiste znaczenie i motywację w swojej pracy, a także gdy otrzymują pozytywne interpersonalne wsparcie oraz działają w efektywnym środowisku pracy. Do pomiaru zaangażowania DDI wykorzystuje kwestionariusz o nazwie E3 składający się z 20 pytań związanych z trzema obszarami; są to:

1) indywidualna wartość - pracownicy czują się bardziej zaangażowani, gdy mają możliwość stworzenia czegoś unikatowego, są samodzielni, moją możliwość osobistego rozwoju;

2) zdefiniowany kierunek pracy - pracownicy czują się bardziej zaangażowani, gdy mają jasny cel, kierunek, do którego dążą, i warunki pracy zapewniające efektywność;

3) wsparcie od otoczenia - pracownicy czują się bardziej zaangażowani, gdy pracują w bezpiecznym kooperatywnym środowisku, przy czym bezpieczeństwo w tym znaczeniu przekłada się na zaufanie i szybkie rozwiązywanie konfliktów.

Tworzenie kultury pracy sprzyjającej samodzielności oraz możliwości wywierania wpływu na otoczenie i wytworzenia/dodania indywidualnej wartości stanowi zatem jeden z kluczowych obszarów sprzyjających zaangażowaniu pracowników. „Słuchanie pracowników dostarczających bardzo szczegółowej wiedzy na temat procesów oraz wdrożenie ich pomysłów na usprawnienie buduje nie tylko odpowiedzialność za zmiany, ale także rozwija kadrę, wzmaga produktywność i poprawia atmosferę w pracy" [Słowik 2016].

Podobne wnioski wynikają z badań Institute for Employment Studies (IES) [Robinson, Perryman i Hayday 2004]. Zgodnie z nimi najważniejsze czynniki budujące zaangażowanie pracowników to:

1) włączenie pracowników w podejmowanie decyzji,

2) możliwość wyrażania przez pracowników swoich idei, zgłaszania pomysłów, przywiązywanie do nich wagi przez menedżerów, cenienie wkładu pracowników,

3) możliwość definiowania swojej pracy przez pracowników,

4) troska organizacji o dobre samopoczucie pracowników.

J. de Jong i D. Hartog [2007, s. 41], omawiając zachowania liderów, które wspierają zaangażowanie i innowacyjność pracowników, podkreślają również rolę delegowania uprawnień oraz dawania podwładnym autonomii zapewniającej niezależność w zakresie wykonywanej pracy. Zdaniem autorów są one istotne zarówno w odniesieniu do inicjatywy, jak i implementacji innowacji. Rolę autonomii w podejmowaniu decyzji podkreśliła również A. Zakrzewska-Bielawska, [2012, s. 25], wymieniając ją wśród podstawowych motywatorów pozafinansowych. 
Warto zwrócić uwagę, że kultura organizacji otwarta na innowacyjne pomysły pracowników może na wielu poziomach korzystnie wpływać na efektywność i elastyczność danej organizacji. Nie tylko bowiem zwiększa poczucie wpływu na organizację u zatrudnionych, ale może stać się ważnym czynnikiem tworzenia przewagi konkurencyjnej przez wprowadzanie nowych, oryginalnych rozwiązań. Biorąc również pod uwagę zmienność i konieczność nieustannego dostosowywania się do coraz to nowych warunków, należy podkreślić, że zwiększanie poczucia wpływu, a więc także psychologicznego poczucia kontroli, zmniejsza u pracowników lęk przed zmianami, który może skutecznie blokować efektywne działanie (por. [Pawlak 2015, s. 57]).

\section{Rola poczucia wpływu na rzeczywistość organizacyjną w kształtowaniu zaangażowania organizacyjnego pracowników w świetle badań własnych}

\subsection{Cel, założenia i metoda badań}

Zagadnienie znaczenia poczucia wpływu pracowników na funkcjonowanie organizacji podjęte zostało również w badaniach zrealizowanych w $2015 \mathrm{r}$. w Katedrze Psychologii i Dydaktyki Uniwersytetu Ekonomicznego w Krakowie ${ }^{1}$. Autorzy badań przyjęli, że poczucie wpływu doświadczanego przez pracowników stanowi jedną $\mathrm{z}$ istotnych determinant poziomu zaangażowania przejawiającego się w różnych formach zachowania się wobec organizacji odpowiadających określonym typom zaangażowania organizacyjnego.

W badaniach wzięło udział 519 osób, w tym $79 \%$ kobiet i $21 \%$ mężczyzn, w wieku 24-50 lat, zatrudnionych w mikro- (31\%), małych (29\%), średnich (18\%) i dużych przedsiębiorstwach (22\%). Staż pracy w danej organizacji wynosił od poniżej 6 miesięcy do 10 lat (95\% badanych). Badania przeprowadzono na Uniwersytecie Ekonomicznym w Krakowie wśród studentów pracujących studiów niestacjonarnych.

Głównym celem badań było zweryfikowanie współzależności pomiędzy stopniem poczucia wpływu pracowników na organizację a poziomem angażowania się w realizację jej celów. Określono trzy zakresy czynności badawczych; są to:

1) ocena świadomości pracowników w zakresie odczuwania wpływu na rzeczywistość organizacyjną,

${ }^{1}$ Analizowana kwestia stanowiła jeden z obszarów szerzej zakrojonych badań, dotyczących psychospołecznych aspektów kształtowania lub wzmacniania zaangażowania pracowników w ich pracę na rzecz organizacji, wykonanych w ramach badań statutowych nr 071/WE-KPD/01/2015/S/5071 przez zespół pracowników Katedry Psychologii i Dydaktyki UEK. 
2) ocena poziomu zaangażowania organizacyjnego pracowników,

3) ustalenie, czy i w jakim stopniu poczucie wpływu pracowników na rzeczywistość organizacyjną współwystępuje z ich zaangażowaniem organizacyjnym.

Aby zrealizować pierwszy zakres czynności badawczych, określono dwa poziomy poczucia wpływu na rzeczywistość organizacyjną w pracy. Pierwszy, podstawowy poziom powiązano z możliwością zgłaszania przez pracowników własnych innowacyjnych propozycji lub korekt doskonalących przebieg procesów operacyjnych i działań pozaoperacyjnych oraz ewentualnego ich wdrażania. Drugi poziom dotyczył większego wpływu na funkcjonowanie organizacji związanego z zapewnieniem pracownikom określonej autonomii na stanowisku pracy, przy założeniu że dysponują odpowiednimi kompetencjami i doświadczeniem zawodowym. Założono, że wyższy stopień poczucia wpływu na rzeczywistość organizacyjną silniej oddziałuje na zaangażowanie pracownika.

Ocena poziomu zaangażowania organizacyjnego pracowników została z kolei przeprowadzona z wykorzystaniem modelu zaangażowania organizacyjnego J. Meyera i N. Allen. Pozwoliło to na rozróżnienie trzech komponentów zaangażowania, tj.: afektywnego, lojalnościowego i trwania. Taki podział umożliwił, zgodnie z założeniami autorów modelu, nie tylko rozpoznanie przyczyn uczestnictwa w organizacji, ale także wyjaśnienie zachowań pracowników odzwierciedlających różne poziomy zaangażowania. Pracownik może się angażować ze względu na: 1) stan wewnętrznej identyfikacji z wartościami organizacji i treścią pracy (zaangażowanie afektywne oparte na emocjach), 2) poczucie powinności ukształtowane przez wzajemne relacje w organizacji (zaangażowanie lojalnościowe uwarunkowane przez normy społeczne oraz poczucie zobowiązania), 3) poczucie konieczności wynikające z braku alternatywnych możliwości zatrudnienia (zaangażowanie trwania powodowane potrzebą kontynuowania pracy ze względu na pewne koszty i straty).

W badaniach założono istnienie silnego związku pomiędzy poczuciem wpływu a zaangażowaniem afektywnym, a także lojalnościowym, w tym szczególnie wyraźnie ujawniającego się na drugim ze wskazanych poziomów wpływu związanym z posiadaniem przez pracowników autonomii. Wyniki badań empirycznych prezentowane w literaturze nie dawały wyczerpującej odpowiedzi w tym zakresie.

Przyjęto następującą hipotezę badawczą: typ i poziom zaangażowania organizacyjnego współwystępuje z określonym poziomem doświadczania przez pracowników wpływu na organizację i przebieg pracy.

Hipotezy szczegółowe były następujące:

1) zainteresowaniu organizacji innowacyjnymi propozycjami pracownika (pierwszy poziom poczucia wpływu) towarzyszy afektywne przywiązanie do organizacji i lojalnościowe zobowiązanie do realizacji jej celów, 
2) uzyskanie autonomii w realizowaniu roli zawodowej (drugi poziom poczucia wpływu) współwystępuje ze wzrostem afektywnego i lojalnościowego wymiaru identyfikacji z organizacją (zaangażowanie afektywne i lojalnościowe),

3) poczuciu wpływu na funkcjonowanie organizacji (poziom zarówno pierwszy, jak i drugi) nie towarzyszy przekonanie o przymusie trwania w organizacji (zaangażowanie trwania).

Czynności badawcze dotyczące rozpoznania stopnia poczucia wpływu wykonano z wykorzystaniem autorskiego kwestionariusza ankiety, którą zatytułowano „Poczucie wpływu pracowników na organizację”. Skala poczucia wpływu obejmowała dwie podskale odpowiednio do określonych stopni poczucia wpływu. Pierwsza podskala i jej ocena stopnia zainteresowania innowacyjnymi propozycjami pracowników została określona na podstawie ustosunkowania się respondentów do stwierdzeń na temat rodzaju komunikacji w firmie, nieformalnych rozmów o przebiegu pracy, zainteresowania pomysłami pracowników i ich wykorzystania w celu podniesienia efektywności działań. Druga podskala umożliwiła rozpoznanie zakresu autonomii w roli zawodowej przez ustosunkowanie się respondentów do stwierdzeń na temat zakresu samodzielności na stanowisku pracy, wpływu na pracę innych pracowników i zespołów oraz decyzje strategiczne. Badani mieli możliwość wyboru odpowiedzi na skali 5-stopniowej (1 - „zdecydowanie nie”, 2 - „,raczej nie”, 3 - „,czasami”, 4 - „,raczej tak”, 5 - „zdecydowanie tak”). Rzetelność zastosowanego narzędzia badawczego sprawdzono za pomocą współczynnika $\alpha$ Cronbacha: 0,878.

Czynności badawcze mające na celu ocenę zaangażowania organizacyjnego z uwzględnieniem wskazanych typów zrealizowano, wykorzystując kwestionariusz skali przywiązania do organizacji J. Meyera i N. Allen w tłumaczeniu M. Makowskiego i M. Wypych, który porównano z jego wcześniejszą polską wersją [Bańka, Bazińska i Wołoska 2002].

Ostatni, trzeci zakres czynności badawczych polegający na rozpoznaniu związków pomiędzy wartościami zastosowanych podskal poczucia wpływu i wartościami przyjętych typów zaangażowania organizacyjnego zrealizowano za pomocą współczynnika korelacji liniowej Pearsona [Kot, Jakubowski i Sokołowski 2010, s. 301-308; Frankfort-Nachmias i Nachmias 2001, s. 414-415]. Testowano jego istotność statystyczną na poziomie 0,05 . W tej części badań wykorzystano dane badawcze uzyskane w pierwszym i drugim etapie, odnoszące się odpowiednio do poczucia wpływu i zaangażowana organizacyjnego pracowników. Obliczone na tej podstawie wskaźniki korelacji pozwoliły określić zakres współwystępowania badanych zjawisk. 


\subsection{Uzyskane rezultaty badawcze}

Zastosowane metody i narzędzia badawcze oraz przyjęta procedura umożliwiły kompleksowe zrealizowanie czynności badawczych, przeprowadzenie analizy i oceny badanych zjawisk oraz zdiagnozowanie zależności pomiędzy nimi. Rezultaty przeprowadzonej analizy korelacyjnej potwierdziły główną hipotezę badawczą i umożliwiły odniesienie się do hipotez szczegółowych. Doświadczanie przez pracowników poczucia wpływu na organizację i przebieg pracy współwystępuje ze wzrostem zaangażowania organizacyjnego. Uwzględnienie wskazanych poziomów wpływu na organizację i typów zaangażowania organizacyjnego pozwoliło na przedstawienie szczegółowych danych w zakresie badanej zależności oraz ich interesujących charakterystyk. Prezentuje je tabela 1.

Tabela 1. Zależność pomiędzy poziomem wpływu na organizację a typem zaangażowania organizacyjnego $(N=519, p<0,05)$

\begin{tabular}{|l|c|c|c|}
\hline \multirow{2}{*}{ Poziom wpływu } & \multicolumn{3}{|c|}{ Typ zaangażowania organizacyjnego } \\
\cline { 2 - 4 } & afektywne & lojalnościowe & trwania \\
\hline $\begin{array}{l}\text { Poczucie wpływu w pracy } \\
\text { (poziom ogólny) }\end{array}$ & $0,452^{\mathrm{a}}$ & $0,384^{\mathrm{a}}$ & $-0,012$ \\
\hline $\begin{array}{l}\text { Zainteresowanie } \\
\text { innowacyjnymi } \\
\text { propozycjami pracownika } \\
\text { (poziom pierwszy) }\end{array}$ & $0,413^{\mathrm{a}}$ & $0,352^{\mathrm{a}}$ & $-0,031$ \\
\hline $\begin{array}{l}\text { Autonomia pracownika } \\
\text { w wypełnianiu roli } \\
\text { zawodowej (poziom drugi) }\end{array}$ & $0,414^{\mathrm{a}}$ & $0,352^{\mathrm{a}}$ & 0,013 \\
\hline
\end{tabular}

${ }^{a}$ Rezultat istotny statystycznie na poziomie co najmniej $p<0,05$.

Źródło: opracowanie własne.

W odniesieniu do pierwszego poziomu wpływu stwierdzono istotną, umiarkowanie pozytywną korelację pomiędzy doświadczaniem przez pracownika zainteresowania menedżerów problemami na stanowisku pracy, propozycjami modyfikowania i doskonalenia pracy oraz ich wykorzystaniem $w$ praktyce a wzrostem znaczenia wykonywanej pracy i wartości organizacyjnych dla pracownika. Zwiększanie zainteresowania innowacyjnymi propozycjami pracownika współwystępuje zatem ze wzrostem zaangażowania afektywnego $(r=0,41)$. Równocześnie we wspomnianych sytuacjach kształtuje się poczucie zobowiązania do lojalności wobec organizacji, rzetelnego realizowania jej celów oraz gotowość do wykorzystywania dokonujących się zmian jako okazji i szans doskonalenia sposobów ich 
osiągania. Zwiększanie zainteresowania innowacyjnymi propozycjami pracownika sprzyja więc również wzrostowi zaangażowania lojalnościowego $(r=0,35)$.

$\mathrm{W}$ odniesieniu do drugiego poziomu wpływu, zgodnie z drugą hipotezą szczegółową, zakładano, że wyższy poziom poczucia wpływu spowoduje silniejszą niż na pierwszym poziomie stymulację zaangażowania afektywnego i lojalnościowego. Uzyskane wyniki tylko częściowo potwierdziły przyjęte założenie. Stwierdzono statystycznie istotną zależność pomiędzy posiadaniem autonomii na stanowisku pracy lub świadomością osobistego wpływu na funkcjonowanie organizacji a identyfikowaniem się z jej wartościami i afektywnym utożsamianiem się $\mathrm{z}$ treścią pracy $(r=0,41)$, ale siła tej zależności jest taka sama jak na pierwszym poziomie wpływu. Podobnie kształtuje się rozważana zależność, gdy uwzględniony zostanie lojalnościowy typ zaangażowania. Zwiększanie poczucia wpływu przez wzrost autonomii na stanowisku lub wpływu na decyzje strategiczne sprzyja wzrostowi zobowiązania do lojalnego działania na rzecz organizacji w takim samym stopniu jak na pierwszym poziomie wpływu $(r=0,35)$.

Uzyskane wyniki potwierdziły trzecią hipotezę szczegółową. Zaprezentowany na rys. 1 wskaźnik korelacji pomiędzy poczuciem wpływu, zarówno na pierwszym, jak i na drugim poziomie, a zaangażowaniem trwania w organizacji wskazuje na brak związku pomiędzy nimi. Oznacza to, że poczuciu wpływu na żadnym z badanych poziomów nie towarzyszy przekonanie o przymusie lub konieczności uczestnictwa w organizacji wynikające z chłodnej kalkulacji strat i zysków związanych $\mathrm{z}$ trwaniem $\mathrm{w}$ organizacji lub brakiem alternatyw na rynku pracy.

Podsumowując rezultaty prezentowanych badań, należy zwrócić uwagę na trzy istotne w kształtowaniu zaangażowania pracowników kwestie: 1) poczucie wpływu, jakiego doświadczać mogą pracownicy, jest ważną stymulantą ich zaangażowania $\mathrm{w}$ działalność organizacji, 2) różne (przyjęte w badaniu) poziomy czy też sposoby zwiększania poczucia wpływu mają dla pracowników podobne znaczenie, 3) zakładany większy wzrost zaangażowania w sytuacjach powierzania pracownikom większego zakresu wpływu (autonomii) nie został potwierdzony w badaniach.

\subsection{Analiza i omówienie wyników badań}

Zaprezentowane rezultaty badawcze pozwalają na sformułowanie interesujących wniosków. Ogólnie rzecz biorąc, potwierdzają one, że zainteresowanie menedżerów innowacyjnymi pomysłami pracowników oraz autonomia w wypełnianiu roli zawodowej korelują z zaangażowaniem organizacyjnym. Zwrócenie uwagi na ten aspekt w zarządzaniu pracownikami może przynieść konkretne korzyści organizacji dzięki zwiększeniu ich zaangażowania w sprawy organizacji w wymiarze afektywnym i lojalnościowym. Jest to szczególnie ważne współcześnie, gdy tak duże 
jest znaczenie kapitału ludzkiego we współczesnej gospodarce opartej na wiedzy oraz zdolność organizacji do efektywnego funkcjonowania w warunkach zmiany.

Bardziej skomplikowana wydaje się analiza uwzględniająca różne poziomy wpływu pracowników na rzeczywistość organizacyjną. Aby poprawnie zinterpretować wyniki badań wskazujące na to, że oba przyjęte w badaniach poziomy zwiększania poczucia wpływu mają dla pracowników podobne znaczenie, a autonomia nie zwiększa zaangażowania, przyjęto trzy kryteria analizy. Zostały one powiązane $\mathrm{z}$ charakterystyką grupy badawczej i mogą mieć znaczenie w procesie oddziaływania na zaangażowanie pracowników w danej organizacji. Są to: predyspozycje indywidualne lub wcześniejsze doświadczenia, charakter pracy lub zajmowane stanowisko oraz uwarunkowania społeczno-ekonomiczne realizowanych badań.

\section{Predyspozycje indywidualne lub wcześniejsze doświadczenia}

Fakt, że w badanej grupie zapewniona pracownikowi autonomia nie zwiększa zaangażowania, może wynikać z subiektywnego przekonania o niskim poziomie możliwości wywierania większego wpływu lub z wcześniejszych negatywnych doświadczeń. Należy bowiem zauważyć, że osoby, które postrzegają siebie jako mało sprawcze i mające ograniczone możliwości wpływu na rzeczywistość bądź też skłonne do podporządkowania się, mogą czuć się zaangażowane już wtedy, gdy znajdują osobiste znaczenie i motywację w pracy, a także gdy otrzymują interpersonalne wsparcie, właściwe pierwszemu z wyróżnionych poziomów wpływu. Z kolei osoby o negatywnych doświadczeniach w środowisku pracy, związanych np. z brakiem uznania dla ich kompetencji i możliwości wynikającym $\mathrm{z}$ instrumentalnego traktowania pracowników, albo pracujące $\mathrm{z}$ menedżerami traktującymi autonomię pracowników jako zagrożenie dla ich potrzeby kontroli, mają zazwyczaj tendencję do ostrożnego formułowania swoich oczekiwań co do wpływu, jaki mogłyby mieć na działalność organizacji. Wcześniejsze negatywne doświadczenia mogą też powodować, że bardziej doceniają nawet drobne przejawy zainteresowania ich pracą.

\section{Charakter pracy lub zajmowane stanowisko}

Potrzeba poczucia wpływu może zależeć również od rodzaju pracy i pozycji w organizacji. Wykonywanie stosunkowo prostych zadań zawodowych o mniejszym zakresie odpowiedzialności czy zajmowanie niższych stanowisk w strukturze organizacyjnej - co można z pewną ostrożnością zakładać w odniesieniu do badanej grupy, czyli pracujących studentów studiów niestacjonarnych - wpływać będzie na oczekiwania pracownika m.in. w zakresie autonomii. Może to oznaczać, że satysfakcja z wzajemnych relacji pojawi się już w warunkach okazania przez menedżera zainteresowania pracą i problemami zawodowymi pracownika. Ocze- 
kiwanie możliwości wpływu będzie zatem adekwatne do miejsca zajmowanego w strukturze organizacyjnej.

\section{Uwarunkowania społeczno-ekonomiczne realizowanych badań}

Należy również wziąć pod uwagę, że badania zrealizowane zostały w warunkach charakterystycznych dla rynku pracodawcy, który cechuje przedmiotowy stosunek do pracownika. Może to powodować, że każdy przejaw zainteresowania pracownikiem, jego poważnego potraktowania, w szczególności uznania dla jego doświadczenia i kompetencji zawodowych, może wzmacniać motywację pracownika i oddanie dla wykonywanej pracy. W nowych warunkach tworzącego się rynku pracownika oczekiwania pracowników będą być może większe i poczucie wpływu na rzeczywistość organizacyjną charakterystyczne dla pierwszego badanego poziomu może okazać się niewystarczające. Sugerują to coraz wyraźniej zarysowujące się różnice pokoleniowe pomiędzy pracownikami dojrzałymi, z dłuższym stażem pracy, a tymi, którzy dopiero wkraczają na rynek pracy i mają coraz większe oczekiwania wobec pracodawcy. Zdaniem autorek zasadne będzie zbadanie tej kwestii w kolejnym etapie badań, gdy rynek pracownika już się ukształtuje i skrystalizują się oczekiwania nowych pokoleń pracowniczych.

Zaprezentowane kryteria i dokonana na ich podstawie interpretacja uzyskanych rezultatów wskazują, że istniejące w przeprowadzonym procesie badawczym ograniczenia mogą zostać wyeliminowane przez uwzględnienie szerszego zakresu danych opisujących badaną populację pracowników i warunki realizacji badań. W kolejnych badaniach z tego zakresu pożądane byłoby wprowadzenie dodatkowych zmiennych pozwalających na bardziej precyzyjną psychologiczną charakterystykę badanej grupy, takich jak predyspozycje psychiczne i wcześniejsze doświadczenia związane z odczuwaniem wpływu w pracy. Kolejnym ważnym aspektem badań powinno być określenie miejsca badanych w strukturze organizacyjnej i charakteru/stanowiska pracy. Niezwykle istotnym czynnikiem byłoby także bardziej szczegółowe rozpoznanie uwarunkowań społeczno-gospodarczych określających oczekiwania i zachowania różnych grup pracowniczych. Uwzględnienie tych danych pozwoli odnieść się do analizowanej współzależności i zweryfikować prezentowane wnioski.

\section{Zakończenie}

Podsumowując, należy stwierdzić, że wyniki przeprowadzonych badań potwierdziły, że zapewnienie pracownikom poczucia wpływu na rzeczywistość organizacyjną pozytywnie oddziałuje na ich zaangażowanie w aspekcie afektywnym i lojalnościowym. Pozwala ono na rzeczywiste zwiększanie wartości kapitału 
ludzkiego organizacji, która dzięki temu będzie miała pracowników identyfikujących się z jej celami, gotowych na doskonalenie swoich umiejętności, a nie poprzestających na status quo, oraz chętnych do pomocy [Robinson, Perryman i Hayday 2004] i kreatywnego rozwiązywania zadań. Zaangażowanie w bezpośredni sposób przekładać się będzie na efektywność organizacji. Jest ono szczególnie istotne w kontekście wzrostu znaczenia zarządzania wiedzą i kapitałem intelektualnym, gdyż sprzyja większej gotowości do twórczego myślenia, innowacyjności i dzielenia się wiedzą.

Zwiększanie poczucia wpływu może w zależności od potrzeb i możliwości danej organizacji dotyczyć pierwszego lub drugiego poziomu wyszczególnionego w badaniu: związanego z możliwością zgłaszania przez pracowników własnych innowacyjnych propozycji lub korekt doskonalących przebieg procesów operacyjnych oraz ewentualnego ich wdrażania bądź związanego z pozostawianiem pracownikom określonego, adekwatnego do ich kompetencji zakresu autonomii w realizacji roli zawodowej.

Na podstawie wyników badań można jednak wyciągnąć wniosek, że nie tyle sam zakres wpływu, co podmiotowe podejście do pracownika leżące u podstaw poczucia wpływu na rzeczywistość organizacyjną ma istotne znaczenie w kształtowaniu jego zaangażowania w pracę. Podmiotowe traktowanie wiązać się może m.in. $\mathrm{z}$ różnorodnymi formami potwierdzania przydatności kompetencji pracownika, a także z przekonaniem o znaczeniu doświadczania stanów psychicznych związanych z poczuciem sensu, satysfakcji z zaplanowanych i wykonywanych zadań oraz autorstwa/współautorstwa działań. To stosunek do pracownika i jego potencjału zawodowego, znajdujący swój wyraz w różnych formach umożliwiania wpływu na organizację, decyduje o efektach współdziałania z zatrudnionym we wszystkich wymiarach związanych z pracą zawodową. Podmiotowe traktowanie może w zależności od stanowiska, predyspozycji zawodowych czy osobowościowych oraz potrzeb danego pracownika oznaczać różne formy wsparcia w realizacji jego zadań oraz stwarzanie przestrzeni do samodzielnego działania. Mogą to być zarówno nieformalne rozmowy o problemach związanych z wykonywaną pracą i danym stanowiskiem, stworzenie możliwości zgłaszania swoich trudności czy postulatów, jak też otwartość na innowacyjne pomysły pracownika, a następnie w przypadku ich pozytywnego zweryfikowania - ich wykorzystywanie w praktyce. Może to być też zapewnianie pracownikom większego wpływu przez umożliwienie im samodzielnego podejmowania decyzji na stanowisku pracy, liczenie się z ich opinią w zakresie rozwiązań organizacyjnych, stwarzanie warunków wpływania na wykonanie pracy przez innych pracowników, a także na decyzje strategiczne. Implementacja tego typu rozwiązań czy wdrażanie preferowanych działań powinny być jednak zawsze oparte na rozpoznaniu potrzeb danej organizacji i zatrudnionych w niej pracowników, by obie strony mogły skorzystać z efektywnej współpracy. 


\section{Literatura}

Adamska-Chudzińska M. [2015], Zaangażowanie organizacyjne pracowników jako źródło uczestnictwa w organizacji, ,Zeszyty Naukowe Uniwersytetu Ekonomicznego w Krakowie", nr 8, https://doi.org/10.15678/znuek.2015.0944.0804.

Allen N., Meyer J. [1990], The Measurement and Antecedents of Affective, Continuance, and Normative Commitment to the Organization, ,Journal of Occupational and Organizational Psychology", vol. 63, nr 1, https://doi.org/10.1111/j.2044-8325.1990. tb00506.x.

Bańka A., Bazińska R., Wołoska A. [2002], Polska wersja Meyera i Allen Skali Przywiqzania do Organizacji, „Czasopismo Psychologiczne”, nr 8.

Bernthal P.R. [2009], Measuring Employee Engagement, http://www.ddiworld.com/pdf/ ddi_MeasuringEmployeeEngagement_wp.pdf (data dostępu: 15.06.2017).

Conley Ch. [2015], Droga na szczyt, Wydawnictwo Charaktery, Kielce.

Engaged Employees Inspire Company Innovation [2012], „Gallup Business Journal”, Gallup Study, http://businessjournal.gallup.com/kontent/24880/gallup study-engaged-employees-inspire-company.aspx (data dostępu: 15.06.2017).

Frankfort-Nachmias Ch., Nachmias D. [2001], Metody badawcze w naukach społecznych, Zysk i S-ka, Poznań.

Gliszczyńska X. [1990], Skala I-E w Pracy. Technika pomiaru poczucia kontroli w sytuacji pracy, Pracownia Testów Psychologicznych PTP, Warszawa.

Harter J.K., Schmidt F.L., Hayes T.L. [2002], Business-unit-level Relationship between Employee Satisfaction, Employee Engagement, and Business Outcomes: A Meta- analysis, ,Journal of Applied Psychology”, vol 87, nr 2, https://doi.org/10.1037//00219010.87.2.268.

Havighurst R.J. [1972], Developmental Tasks and Education, McKay, Chicago.

Johnson R.E., Groff K.W., Taing M.U. [2009], Nature of the Interactions among Organizational Commitments: Complementary, Competitive or Synergistic?, „British Journal of Management", vol. 20, nr 4, https://doi.org/10.1111/j.1467-8551.2008.00592.x.

Jong J.P.J. de, Hartog D.N.D. [2007], How Leaders Influence Employees' Innovative Behaviour, „European Journal of Innovation Management”, vol. 10, nr 1, https://doi.org/ $10.1108 / 14601060710720546$.

Juchnowicz M. [2010], Zarzq̨dzanie przez zaangażowanie, PWE, Warszawa.

Kostera M. [2008], Współczesne koncepcje zarzqdzania, Wydawnictwa Akademickie i Profesjonalne, Warszawa.

Kot S.M., Jakubowski J., Sokołowski A. [2010], Statystyka, Difin, Warszawa.

Łaguna M., Mielniczuk E., Żaliński A., Wałachowska K. [2015], Przywiqzanie do organizacji i zaangażowanie $w$ prace - koncepcje teoretyczne i problemy terminologiczne, „Medycyna Pracy”, nr 66(2).

Moczydłowska M.J. [2013], Zaangażowanie pracowników, aspekty psychologiczne i spoteczne, ,Myśl Ekonomiczna i Polityczna”, nr 4.

Pawlak J. [2015], Podmiotowość i partycypacja pracowników a zaangażowanie i odpowiedzialność w zespole w sytuacji zmiany, „Zeszyty Naukowe Uniwersytetu Ekonomicznego w Krakowie", nr 8, https://doi.org/10.15678/znuek.2015.0944.0805.

Robinson D., Perryman S., Hayday S. [2004], The Drivers of Employee Engagement, Report 408, Institute for Employment Studies, April. http://www.employmentstudies. co.uk/system/files/resources/files/408.pdf (data dostępu: 15.06.2017). 
Rotter J.B. [1990], Poczucie wewnętrznej versus zewnętrznej kontroli wzmocnień, „Nowiny Psychologiczne”, nr 5/6.

Shore L.M., Wayne S.J. [1993], Commitment and Employee Behavior: Comparison of Affective Commitment and Continuance Commitment with Perceived Organizational Support, ,Journal of Applied Psychology”, vol. 78, nr 5, https://doi.org/10.1037//00219010.78.5.774.

Słowik J. [2016], Zaangażowani pracownicy to klucz do sukcesu, „Harvard Business Review. Polska. nr 3.

Zakrzewska-Bielawska A. [2012], Istota procesu zarzqdzania [w:] Podstawy zarzqdzania, red. A. Zakrzewska-Bielawska, Wolters Kluwer, Warszawa.

\section{Employee Influence and Commitment to Their Organisations}

(Abstract)

With competitiveness on the rise and conditions for the functioning of modern organisations changing rapidly, it has become more and more important to recruit and retain employees who, in addition to being highly competent, will also be ready to identify with the goals and mission of the organisation. An important factor in this respect is employees having a sense of influence on the organisation. The aim of the article is to present and discuss the results of research on the relationship between the sense of influence and readiness of employees to engage in work and their commitment to the organisation. Two ranges of the sense of influence at work were distinguished. The first involved the possibility of submitting one's own innovative proposals to improve the operational processes while the second consisted in entrusting employees with a certain scope of autonomy at the workplace. The results confirmed a correlation between the sense of influence and commitment in its affective and normative aspects. At the same time, it was found that experiencing a sense of influence on one or the other level influences one's commitment to the organisation to a similar degree.

Keywords: employee, sense of influence, organisational commitment, organisation. 